\title{
VARIJABILNOST SVOJSTAVA PLODOVA KOD PROVENIJENCIJA DIVLJE TREŠNJE (Prunus avium L.) U SRBIJI
}

\author{
VARIATIONS IN FRUIT TRAITS OF WILD CHERRY \\ (Prunus avium L.) PROVENANCES IN SERBIA
}

Vladan POPOVIĆ1, Aleksandar LUČIĆ ${ }^{1}$ Ivona KERKEZ JANKOVIĆ², Ljubinko RAKONJAC'1, Saša BOGDAN³

\section{SAŽETAK}

Prirodne populacije divlje trešnje u Srbiji nalaze se blizu južne granice areala ove značajne šumske vrste. Opstanak rubnih provenijencija, u Srbiji i široj regiji jugoistoka Europe, ugrožen je uslijed promjene klime, male veličine populacija, niske kompetitivnosti vrste i dr. Zbog toga se preporučuje umjetno potpomaganje obnove populacija uz proširivanje njihove genske raznolikosti. Iako je poznavanje razine i strukture genetske raznolikosti preduvjet njene učinkovite konzervacije i korištenja, istraživanja ove tematike na divljoj trešnji u regiji su rijetka. Cilj ovog istraživanja bio je utvrditi razinu i obrazac fenotipske varijabilnosti za morfološka svojstva plodova, a raspravljena je i mogućnost povezanosti obrasca fenotipske varijabilnosti s genetskom diferencijacijom provenijencija.

Plodovi su prikupljeni u devet prirodnih populacija. Analizirano je deset morfoloških svojstava plodova i utrđena je prosječna klijavost provenijencija. Najmanje varijabilnim pokazalo se svojstvo širina ploda (CV $=6.2 \%)$, dok je najvarijabilnije svojstvo bila debljina peteljke $(\mathrm{CV}=29.4 \%)$. Analizom varijance utvrđeno je da su se provenijencije međusobno statistički značajno razlikovale po svim istraživanim morfološkim svojstvima plodova $(\mathrm{p}<0.01 ; \alpha=0.05)$, izuzev po svojstvu debljina peteljke $(\mathrm{p}=0.92)$. Iako je varijabilnost između provenijencija bila statistički značajna, razina unutarpopulacijske varijabilnosti bila je znatno veća (41.2-52.1\%) od međupopulacijske diferencijacije (5.315.2\%). Obrazac diferencijacije između provenijencija utvrđen je korelacijskom analizom prosječnih vrijednosti svojstava s klimatsko-geografskim varijablama provenijencija, pri čemu su se debljina ploda i duljina peteljke pokazali kao korisna dijagnostička svojstva. Prosječna debljina ploda bila je signifikantno pozitivno korelirana s nadmorskom visinom $(\mathrm{R}=0.69 ; \mathrm{p}=0.04)$, prosječnom godišnjom količinom snježne oborine $(\mathrm{R}=0.80 ; \mathrm{p}=0.01)$ i prosječnim godišnjim brojem stupanj-dana ispod $0^{\circ} \mathrm{C}(\mathrm{R}=0.70 ; \mathrm{p}=0.04)$. Prosječna duljina peteljke bila je signifikantno negativno korelirana s prosječnom godišnjom količinom snježne oborine $(\mathrm{R}=-0.69 ; \mathrm{p}=0.04)$, a pozitivno s omjerom godišnje temperature $\mathrm{i}$ količine oborina $(\mathrm{R}=0.71 ; \mathrm{p}=0.03)$. Rezultati su pokazali ekoklinalni obrazac fenotipske diferencijacije provenijencija s obzirom na nadmorsku visinu staništa i s njom koreliranim ekološkim varijablama.

Iako su istraživanja obuhvatila fenotipsku varijabilnost plodova iz prirodnih populacija, ovakvi rezultati ukazuju na vjerojatnost genetske diferencijacije provenijencija s obzirom na nadmorsku visinu. To daje temelj preporuci vertikalne sjemenske zonacije areala divlje trešnje u Srbiji, kao i sukladnog korištenja njenog reprodukcijskog materijala u potpomognutoj obnovi. Radi potvrde rezultata ovog istraživanja odnosno preciznije determinacije genetske strukture prirodnih populacija, neophodno je primijeniti metode analiza raznovrsnih fenotipskih svojstava u posebno dizajniranim pokusnim nasadima (npr. testovima provenijencija) kao i analiza prikladnih DNA markera.

KLJUČNE RIJEČl: morfologija, sjeme, fenotipska svojstva, diferencijacija provenijencija, ekoklina.

'Dr. sc. Vladan Popović (vladanpop79@gmail.com), Dr. sc. Aleksandar Lučić, Dr. sc. LJubinko Rakonjac, Institut za šumarstvo, Kneza Višeslava 3, 11000 Beograd ${ }^{2}$ MSc Ivona Kerkez Janković, PhD student, Univerzitet u Beogradu, Šumarski fakultet, Kneza Višeslava 1, 11000 Beograd

${ }^{3}$ Prof. dr. sc. Saša Bogdan, Šumarski fakultet Sveučilišta u Zagrebu, Svetošimunska 25, 10000 Zagreb. 


\section{UVOD}

\section{INTRODUCTION}

Divlja trešnja (Prunus avium L.) je listopadna, entomofilna, alogamna šumska vrsta rasprostranjena širom Europe (CABI 2013). Zbog izuzetnog ekološkog i ekonomskog značaja ova je vrsta predmet različitih programa oplemenjivanja od 1980-tih godina (Ducci i sur. 2013). Smatra se vrstom svjetlosti (heliofit) i relativno otpornom na stresne faktore. U Srbiji je autohtona i javlja se kao samonikla, uglavnom stablimično primješana u mezofilnim šumama hrastova i donjeg pojasa obične bukve (Tomić 2004). Međutim, može se pronaći i u značajno sušim šumskim staništima, te na poljoprivrednim tlima ili kao ostatak iskrčenih šuma (Mratinić i Kojić 1998; Ballian 2000; Mikić 2007; Tančeva Crmarić i sur. 2011; Milatović i sur. 2015).

Bez obzira na rasprostranjenost u vidu raspršenog stablimičnog ili grupimičnog rasporeda, sukladno dosadašnjim spoznajama, protok gena unutar i između populacija se odvija slobodno i relativno brzo, što rezultira niskom stopom genetske diferencijacije populacija (Ducci i sur. 2013). Uz raznovrsne faktore (polinatori, antropogeni utjecaj, raznošenje sjemena pticama itd.), dominatnu ulogu u održavanju visoke razine genetske raznolikosti ima samoinkompatibilnost prilikom oprašivanja. Međutim, s obzirom na njenu izdanačku snagu, genetska konstitucija malih grupa jedinki može biti vrlo niske raznolikosti, tj. može je činiti jedan ili nekoliko genotipova (Frascaria i sur. 1993; Ducci i Santi 1997).

Iako se u Europi divlja trešnja ne smatra ugroženom (Russell 2003), u Srbiji je svrstana u kategoriju vrsta "pod rizikom" (Banković i sur. 2008) zbog niza ugrožavajućih faktora (Russell 2003; Stjepanović 2012; Jagodić 2014). Za potrebe šumarstva se sadnice divlje trešnje proizvode generativnim načinom, tako da su osobine sjemena jedan od ključnih faktora kvalitetne proizvodnje šumskog reprodukcijskog materijala. Sjemenski materijal je vrlo varijabilan po svojim biološkim osobinama, stoga se preporučuje selektiranje sjemenskih izvora i uporaba genetski kvalitetnijeg materijala (Mratinić i Kojić 1998; Kingswell 1998; Piotto i sur. 2003).

Osnovu za upoznavanje adaptivnog potencijala divlje trešnje na nekom području predstavljaju istraživanja genetske raznolikosti i strukture (Popović i Kerkez 2016). Dosadašnja istraživanja ukazuju na značajnu varijabilnost divlje trešnje na fenotipskoj razini (Krüssman 1978; Rakonjac 1993; Jovković 1999; Ballian 2000; Mikić 2007; Ballian i Čabaravdić 2007; Ballian i sur. 201; Mratinić i sur. 2012; Ballian i Mujagić-Pašić 2013; Rakonjaci sur. 2014; Katičić Bogdan i sur. 2015; Popović i Kerkez 2016), kao i na molekularnoj razini (Frascaria i sur. 1993; Ducci i Santi 1997; Ballian 2004; Lacis i sur. 2009; Avramidou i dr. 2010; Turet-Sayar i dr. 2012; Ganopoulos i dr. 2010; Ganopoulos i dr. 2011; Tančeva Crmarić i sur. 2011; Jarni i sur. 2012; De Rogatis i sur. 2013; Ganopoulos i sur. 2013; Barać i sur. 2015; Avramidou i sur. 2015; Campoy i sur. 2016; Ivanovych i Volkov 2018).

Identifikacija ključnih populacija, kao i konzervacija vrijednih genotipova u marginalnom dijelu areala predstavljaju osnovne smjernice za očuvanje i korištenje genofonda divlje trešnje u Europi. Rubne populacije, na granici ekološke niše, vrijedan su izvor gena za očuvanje genofonda cijele vrste, posebice u kontekstu promjene klime (Russell 2003). S obzirom da se Srbija nalazi u blizini južne granice prirodnog areala ove vrste, odabir i istraživanje prirodnih populacija na ovom području je opravdano i nužno kako bi se očuvali i ciljano koristili njeni genetski resursi. Vitalnost i opstanak populacija šumskih drvenastih vrsta u promijenjenim okolišnim prilikama uvjetovani su očuvanjem visokog stupnja njihove genetske raznolikosti, kao temeljem za adaptacijsko-evolucijske procese (Šijačić-Nikolić i Milovanović 2012). Kako bi se stvorili temelji za očuvanje genofonda divlje trešnje i kvalitetno gospodarenje njenim genskim resursima, nužna su detaljna istraživanja razine, obrasca i uzroka genetske raznolikosti odnosno strukture.

Cilj ovog istraživanja bio je utvrditi razinu i obrazac fenotipske varijabilnosti morfoloških svojstava ploda u prirodnim populacijama divlje trešnje u Srbiji, te time pridonijeti poznavanju varijabilnosti prirodnih populacija u rubnom dijelu prirodnog areala. Rezultati dobiveni ovim istraživanjem mogu biti osnova za daljnja istraživanja genetske raznolikosti, začetak oplemenjivanja vrste, kao i za očuvanje njenog genofonda.

\section{MATERIJAL I METODE MATERIAL AND METHODS}

\section{Biljni materijal i izmjere fenotipskih svojstava - Plant material and trait measurements}

Plodovi su sakupljeni u devet prirodnih populacija (provenijencija) divlje trešnje u Republici Srbiji (Slika 1, tablica 1). Svaka populacija bila je zastupljena s deset stabala, dok je od svakog stabla prikupljeno 50 zrelih i u potpunosti razvijenih plodova. Uzorkovana su isključivo fiziološki zrela stabla koja su plodonosila u srpnju 2017. godine.

Uzorkovani plodovi su nakon izmjere macerirani, te su sjemenke odvojene od usplođa. Izbor mjerenih morfoloških svojstava usklađen je s istraživanjem Ballian i sur. (2012). Točnost mjerenja iznosila je $0,1 \mathrm{~mm}$. Ukupno je izmjereno deset morfoloških svojstava: FL- dužina ploda (mm); FWširina ploda $(\mathrm{mm})$; FT-debljina ploda $(\mathrm{mm})$; FM-masa ploda (g); LOS-dužina peteljke (mm); WOS-debljina peteljke (mm); SL-dužina sjemenke (mm); SW-širina sje- 


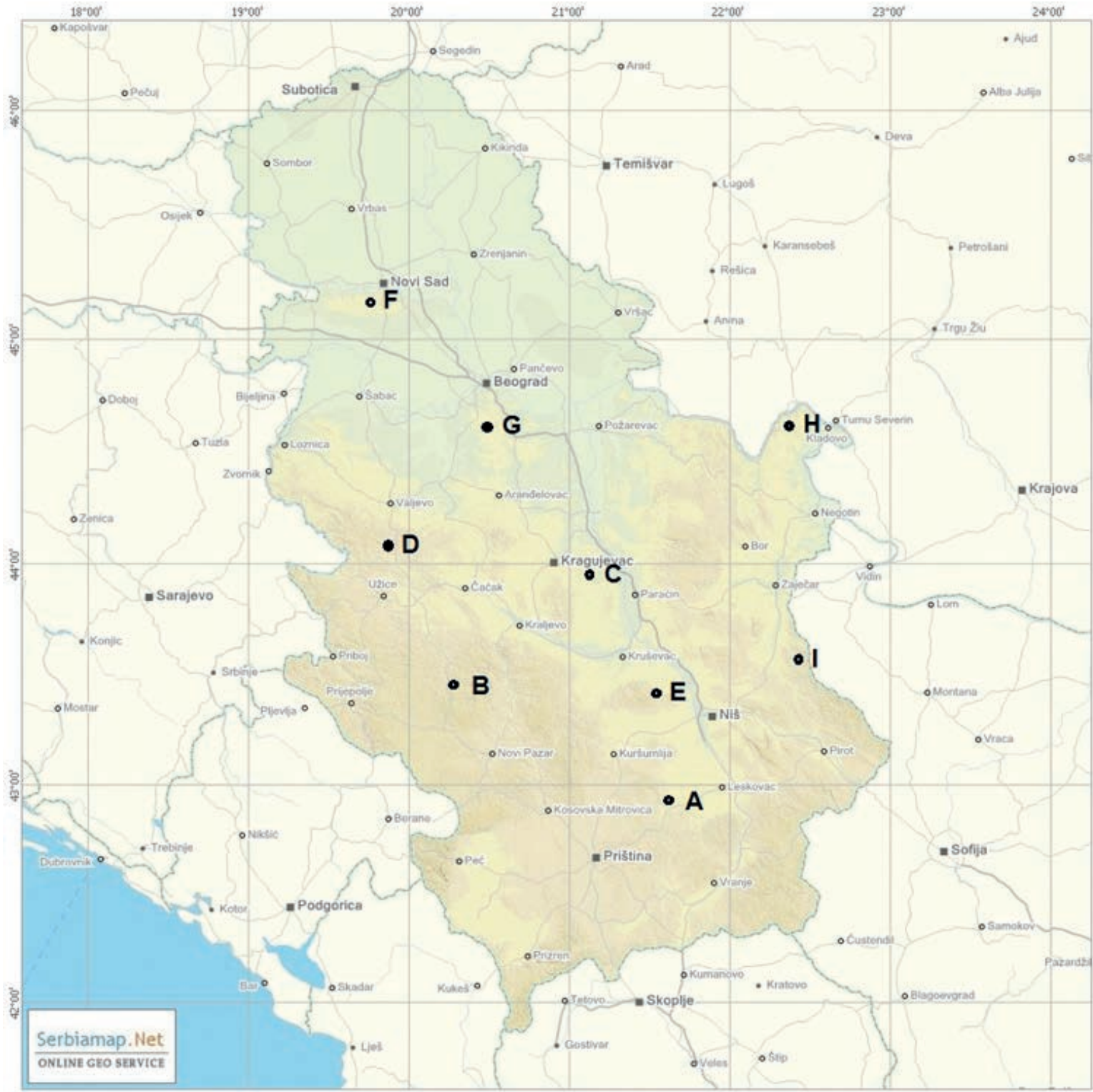

Slika 1. Karta prostornog rasporeda istraživanih provenijencija ( $\mathrm{A}$ - Radan, B - Javor, C - Bešnjaja, D - Divčibare, E - Jastrebac, F - Fruška Gora, G - Lipovica, H - Đerdap, I - Stara Planina).

Figure 1. Map of spatial distribution of studied provenances (A - Radan, B - Javor, C - Bešnjaja, D - Divčibare, E - Jastrebac, F - Fruška Gora, G - Lipovica, H - Đerdap, I - Stara Planina).

menke (mm); ST-debljina sjemenke (mm); SM-masa sjemenke (g).

Prosječna klijavost (GERM) utvrđena je na razini provenijencije u rasadničkom testu, na uzorku od $4 \times 50$ sjemenki po provenijenciji.

\section{Statistička obrada podataka - Statistical analyses}

Statističke analize provedene su korištenjem programa RStudio ver. 1.2.5001 (RStudio Team 2019. RStudio: Integrated Development for R. RStudio, Inc., Boston, MA URL http://www.rstudio.com/), programa SAS/STAT 15.1 (SAS/ STAT software, a free version of SAS University Edition, by SAS Institute Inc., Cary, NC, USA) i programa STATISTICA 7.0 (StatSoft Inc. 2004).
Normalnost podataka prikupljenih izmjerama analizirana je Kolmogorov-Smirnov testom, a homogenost varijanci Levene testom u R-u. Deskriptivna analiza provedena je pomoću procedure MEANS u SAS-u radi izračuna: aritmetičkih sredina $(\mathrm{x})$, standardnih devijacija (SD) i koeficijenata varijacije (CV \%). Analiza varijance (ANOVA) provedena je uporabom procedure MIXED u SAS-u, s ciljem utvrđivanja statistički značajnih razlika između populacija i unutar populacija. Analizirani izvori (faktori) varijabilnosti bili su populacija i stablo, s tim da je faktor stablo bio ugnježden unutar faktora populacija. Za izračun komponenti varijance pojedinih izvora varijabilnosti korištena je REML metoda (engl. Restricted Maximum Likelihood Method). Provedeno je i dodatno testiranje Fisherovim multi- 
Tablica 2. Deskriptivni statistički parametri analiziranih morfoloških svojstava plodova.

Table 2. Descriptive statistics of studied fruit morphology traits.

\begin{tabular}{|c|c|c|c|c|c|c|c|c|c|c|c|}
\hline \multirow{2}{*}{ 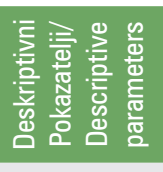 } & \multirow{2}{*}{ 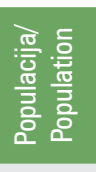 } & \multicolumn{10}{|c|}{$\begin{array}{c}\text { Svojstvo/ } \\
\text { Trait }\end{array}$} \\
\hline & & $\begin{array}{c}\mathrm{FL} \\
(\mathrm{mm})\end{array}$ & $\begin{array}{l}\text { FW } \\
(\mathrm{mm})\end{array}$ & $\begin{array}{c}\mathrm{FT} \\
(\mathrm{mm})\end{array}$ & $\begin{array}{l}\text { FM } \\
(\mathrm{g})\end{array}$ & $\begin{array}{l}\text { LOS } \\
(\mathrm{mm})\end{array}$ & $\begin{array}{l}\text { WOS } \\
(\mathrm{mm})\end{array}$ & $\underset{(\mathrm{mm})}{\mathrm{SL}}$ & $\begin{array}{c}1+S W \\
(\mathrm{~mm})\end{array}$ & $\underset{(\mathrm{mm})}{\mathrm{ST}}$ & $\begin{array}{l}S M \\
\text { (g) }\end{array}$ \\
\hline \multirow{9}{*}{$x$} & A & 10,58 & 10,02 & 9,88 & 1,17 & 37,27 & 0,60 & 7,25 & 5,85 & 4,62 & 0,12 \\
\hline & B & 10,93 & 10,56 & 10,54 & 1,39 & 35,19 & 0,59 & 7,83 & 6,60 & 5,01 & 0,14 \\
\hline & C & 9,67 & 9,73 & 8,99 & 1,18 & 36,85 & 0,61 & 6,60 & 5,92 & 4,55 & 0,11 \\
\hline & $D$ & 10,61 & 9,62 & 9,03 & 1,27 & 39,90 & 0,59 & 7,73 & 5,99 & 4,74 & 0,14 \\
\hline & E & 10,78 & 9,87 & 9,30 & 1,51 & 41,09 & 0,60 & 7,90 & 6,68 & 5,43 & 0,17 \\
\hline & $\mathrm{F}$ & 10,41 & 9,96 & 9,00 & 1,36 & 38,71 & 0,59 & 7,30 & 6,33 & 5,12 & 0,14 \\
\hline & G & 10,76 & 10,04 & 9,54 & 1,24 & 41,32 & 0,61 & 7,51 & 5,90 & 4,59 & 0,14 \\
\hline & $\mathrm{H}$ & 10,34 & 9,82 & 8,89 & 1,23 & 42,06 & 0,58 & 6,96 & 6,04 & 4,63 & 0,12 \\
\hline & I & 11,49 & 9,83 & 9,25 & 1,34 & 41,85 & 0,58 & 7,92 & 6,11 & 4,76 & 0,14 \\
\hline \multirow{12}{*}{$\min$} & mean & 10,62 & 9,94 & 9,38 & 1,30 & 39,36 & 0,59 & 7,44 & 6,16 & 4,83 & 0,14 \\
\hline & A & 8,72 & 8,45 & 9,11 & 0,79 & 20,24 & 0,24 & 5,42 & 4,35 & 4,00 & 0,08 \\
\hline & B & 9,10 & 9,14 & 9,34 & 0,91 & 20,10 & 0,11 & 5,99 & 5,41 & 4,00 & 0,09 \\
\hline & C & 8,49 & 8,41 & 8,44 & 0,78 & 20,39 & 0,25 & 5,41 & 5,03 & 4,02 & 0,06 \\
\hline & $D$ & 8,38 & 8,21 & 8,03 & 0,74 & 21,92 & 0,27 & 5,41 & 5,40 & 4,00 & 0,08 \\
\hline & $E$ & 7,09 & 7,65 & 7,25 & 0,67 & 23,83 & 0,15 & 4,05 & 5,40 & 4,08 & 0,11 \\
\hline & $\mathrm{F}$ & 6,96 & 7,97 & 7,23 & 0,92 & 22,62 & 0,23 & 3,75 & 5,41 & 4,01 & 0,09 \\
\hline & G & 8,21 & 8,26 & 8,65 & 0,73 & 26,14 & 0,11 & 5,47 & 4,18 & 4,02 & 0,08 \\
\hline & $\mathrm{H}$ & 7,56 & 7,62 & 7,79 & 0,55 & 23,80 & 0,31 & 5,42 & 5,31 & 4,00 & 0,08 \\
\hline & 1 & 9,69 & 7,68 & 7,11 & 0,71 & 23,80 & 0,31 & 5,98 & 5,35 & 4,01 & 0,09 \\
\hline & mean & 8,24 & 8,15 & 8,14 & 0,76 & 22,54 & 0,22 & 5,21 & 5,09 & 4,02 & 0,08 \\
\hline & A & 12,10 & 11,28 & 11,00 & 1,87 & 51,01 & 1,08 & 8,27 & 7,14 & 5,70 & 0,18 \\
\hline \multirow{8}{*}{$\max$} & B & 12,29 & 12,06 & 11,81 & 2,42 & 57,94 & 1,25 & 8,98 & 8,07 & 6,17 & 0,24 \\
\hline & C & 11,04 & 10,94 & 10,12 & 1,89 & 58,83 & 1,08 & 7,96 & 7,07 & 5,70 & 0,18 \\
\hline & $D$ & 11,93 & 10,95 & 11,20 & 1,93 & 60,36 & 0,97 & 9,02 & 7,14 & 5,94 & 0,22 \\
\hline & $E$ & 12,78 & 11,39 & 10,35 & 2,61 & 57,59 & 0,95 & 9,74 & 8,08 & 6,30 & 0,27 \\
\hline & $\mathrm{F}$ & 11,76 & 11,69 & 10,18 & 2,24 & 61,26 & 1,06 & 8,60 & 8,03 & 6,13 & 0,22 \\
\hline & G & 12,56 & 11,26 & 11,30 & 1,92 & 60,57 & 1,03 & 9,33 & 7,04 & 5,72 & 0,21 \\
\hline & H & 12,40 & 11,23 & 10,12 & 1,93 & 60,25 & 0,96 & 8,64 & 7,00 & 5,87 & 0,17 \\
\hline & 1 & 13,12 & 11,02 & 10,54 & 2,31 & 57,97 & 1,68 & 9,41 & 7,54 & 5,92 & 0,21 \\
\hline \multirow{11}{*}{ sd } & mean & 12,22 & 11,31 & 10,74 & 2,12 & 58,42 & 1,12 & 8,88 & 7,46 & 5,94 & 0,21 \\
\hline & A & 0,75 & 0,51 & 0,49 & 0,23 & 8,05 & 0,18 & 0,71 & 0,47 & 0,47 & 0,02 \\
\hline & B & 0,52 & 0,74 & 0,65 & 0,33 & 9,52 & 0,20 & 0,48 & 0,74 & 0,67 & 0,03 \\
\hline & C & 0,74 & 0,39 & 0,42 & 0,19 & 8,28 & 0,18 & 0,74 & 0,36 & 0,41 & 0,02 \\
\hline & D & 0,72 & 0,50 & 0,74 & 0,26 & 8,72 & 0,16 & 0,71 & 0,33 & 0,54 & 0,02 \\
\hline & $\mathrm{E}$ & 1,04 & 0,83 & 1,04 & 0,46 & 9,12 & 0,17 & 1,09 & 0,80 & 0,58 & 0,04 \\
\hline & $\mathrm{F}$ & 0,83 & 0,70 & 0,70 & 0,30 & 8,93 & 0,19 & 0,75 & 0,64 & 0,59 & 0,03 \\
\hline & G & 1,06 & 0,56 & 0,59 & 0,25 & 6,53 & 0,16 & 0,98 & 0,48 & 0,48 & 0,03 \\
\hline & H & 1,07 & 0,64 & 0,53 & 0,27 & 8,49 & 0,14 & 0,83 & 0,30 & 0,49 & 0,02 \\
\hline & 1 & 1,23 & 0,63 & 0,73 & 0,30 & 7,82 & 0,19 & 0,69 & 0,44 & 0,57 & 0,02 \\
\hline & mean & 0,88 & 0,61 & 0,65 & 0,29 & 8,38 & 0,17 & 0,78 & 0,51 & 0,53 & 0,03 \\
\hline
\end{tabular}




\begin{tabular}{|c|c|c|c|c|c|c|c|c|c|c|c|}
\hline \multirow{2}{*}{ 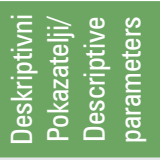 } & \multirow{2}{*}{ 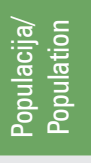 } & \multicolumn{10}{|c|}{$\begin{array}{c}\text { Svojstvo/ } \\
\text { Trait }\end{array}$} \\
\hline & & $\begin{array}{c}\mathrm{FL} \\
(\mathrm{mm})\end{array}$ & $\begin{array}{c}\mathrm{FW} \\
(\mathrm{mm})\end{array}$ & $\begin{array}{c}\text { FT } \\
(\mathrm{mm})\end{array}$ & $\begin{array}{l}\text { FM } \\
(\mathrm{g})\end{array}$ & $\begin{array}{l}\text { LOS } \\
(\mathrm{mm})\end{array}$ & $\begin{array}{l}\text { WOS } \\
(\mathrm{mm})\end{array}$ & $\begin{array}{c}\mathrm{SL} \\
(\mathrm{mm})\end{array}$ & $\begin{array}{c}1+S W \\
(\mathrm{~mm})\end{array}$ & $\begin{array}{c}\text { ST } \\
(\mathrm{mm})\end{array}$ & $\begin{array}{l}\text { SM } \\
\text { (g) }\end{array}$ \\
\hline \multirow{10}{*}{ CV (\%) } & A & 7,10 & 5,14 & 4,99 & 19,93 & 21,61 & 29,66 & 9,80 & 8,02 & 10,21 & 18,19 \\
\hline & B & 4,75 & 7,05 & 6,19 & 23,98 & 27,05 & 33,53 & 6,17 & 11,28 & 13,28 & 21,94 \\
\hline & C & 7,63 & 4,01 & 4,67 & 16,37 & 22,47 & 29,55 & 11,25 & 6,13 & 9,06 & 17,02 \\
\hline & D & 6,79 & 5,21 & 8,15 & 20,35 & 21,86 & 27,51 & 9,15 & 5,50 & 11,50 & 17,55 \\
\hline & $E$ & 9,67 & 8,43 & 11,15 & 30,22 & 22,19 & 28,69 & 13,76 & 12,01 & 10,61 & 23,29 \\
\hline & $\mathrm{F}$ & 7,99 & 7,00 & 7,79 & 21,89 & 23,08 & 31,84 & 10,34 & 10,16 & 11,50 & 21,15 \\
\hline & G & 9,88 & 5,58 & 6,14 & 20,08 & 15,80 & 26,63 & 13,02 & 8,15 & 10,42 & 19,43 \\
\hline & H & 10,34 & 6,55 & 5,94 & 21,96 & 20,18 & 24,42 & 11,89 & 5,03 & 10,60 & 16,25 \\
\hline & 1 & 10,71 & 6,45 & 7,93 & 22,36 & 18,68 & 32,53 & 8,73 & 7,20 & 11,97 & 16,14 \\
\hline & mean & 8,32 & 6,16 & 6,99 & 21,91 & 21,43 & 29,37 & 10,46 & 8,16 & 11,02 & 19,00 \\
\hline
\end{tabular}

plim testovima signifikantnosti najmanjih kvadratnih razlika (LSD) s ciljem utvrđivanja populacija koje se međusobno statistički značajno razlikuju. Pearson-ova korelacijska analiza provedena je uporabom Hmisc paketa u R-u (Harrell i dr. 2019) radi utvrđivanja značajnih povezanosti između analiziranih svojstava, kao i povezanosti između svojstava i klimatskih varijabli izvornih staništa provenijencija. Ulazni podaci za korelacijsku analizu bile su artimetičke sredine provenijencija za analizirana fenotipska svojstva i različite klimatske varijable povezane s njihovim izvornim sastojinama. Za karakterizaciju dugoročnih klimatskih uvjeta izvornih sastojina korišteni su interpolirani podaci o klimi za referentno razdoblje 1981.-2009. koji su generirani softverom ClimateEU (Hamann, A., Wang T., Spittlehouse DL, Murdock TQ 2013: ClimateEU, neobjavljeni softverski paket za Europu, dostupan na http://www. ualberta.ca/ ahamann/data/climateeu.html). Detaljno objašnjenje procjene svih dostupnih klimatskih varijabli koje daje softver ClimateEU može se naći u Wang i dr. (2012).

\section{REZULTATI}

\section{RESULTS}

\section{Dekriptivna analiza morfoloških svojstava - Descriptive analysis of morphological traits}

U tablici 2 prikazani su deskriptivni statistički parametri za istraživana svojstva. Srednja vrijednost dužine plodova (FL) iznosila je $10.62 \mathrm{~mm}$. Najveća srednja vrijednost je utvrđena u populaciji Stara Planina (11,49 mm), a najmanja u populaciji Bešnjaja $(9.67 \mathrm{~mm})$. Najveća vrijednost dužine ploda izmjerena je u populaciji Stara Planina (13.12 $\mathrm{mm})$, a najmanja u populaciji Jastrebac $(7.09 \mathrm{~mm})$. Najveća vrijednost koeficijenta varijabilnosti utvrđena je u populaciji Stara Planina (10.71\%), a najmanja u populaciji Javor (4.75\%).
Srednja vrijednost širine plodova (FW) iznosila je $9.94 \mathrm{~mm}$ i kretala se od $9.62 \mathrm{~mm}$ u populaciji Divčibare do $10.56 \mathrm{~mm}$ u populaciji Javor. Najniža vrijednost je izmjerena u populaciji Đerdap (7.62 mm), a najviša u populaciji Javor (12.06 $\mathrm{mm}$ ). Koeficijent varijabilnosti kretao se od $4.01 \%$ kod populacije Bešnjaja, do $8.43 \%$ kod populacije Jastrebac.

Srednja vrijednost debljine plodova iznosila je $9.38 \mathrm{~mm}$. Najveća srednja vrijednost je izmjerena u populaciji Javor $(10.54 \mathrm{~mm})$, a najmanja u populaciji Đerdap $(8.89 \mathrm{~mm})$. Najniža apsolutna vrijednost debljine ploda je izmjerena u populaciji Stara Planina $(7.11 \mathrm{~mm})$, a najviša u populaciji Javor (11.81 mm). Vrijednost koeficijenta varijabilnosti kretao se od $4.67 \%$ u populaciji Divčibare do $11.15 \%$ u populaciji Jastrebac.

Srednja vrijednost mase ploda iznosila je 1.30 g. Najveću srednju vrijednost mase ploda imala je populacija Jastrebac (1.51 g), a najmanju populacija Radan (1.17 g). Najmanja vrijednost mase ploda od 0.55 g izmjerena je u populaciji Đerdap, a najveća u populaciji Jastrebac (2.61 g). Najmanja vrijednost koeficijenta varijabilnosti je utvrđena kod populacije Divčibare (16.37\%), a najveća kod populacije Javor (23.98\%).

Srednja vrijednost dužine peteljke (LOS) iznosila je 39.36 $\mathrm{mm}$. Populacija Đerdap imala je najveću srednju vrijednost dužine peteljke $(42.06 \mathrm{~mm})$, a populacija Javor najmanju (35.19 mm). Najmanja vrijednost dužine peteljke izmjerena je u populaciji Javor $(20.10 \mathrm{~mm})$, a najveća u populaciji Fruška gora $(61.26 \mathrm{~mm})$. Vrijednost koeficijenta varijabilnosti bila je najniža u populaciji Lipovica (15.80\%), a najviša u populaciji Javor (27.05\%).

Srednja vrijednost debljine peteljke (WOS) iznosila je 0.59 $\mathrm{mm}$. Najveću srednju vrijednost imale su populacije Divčibare i Lipovica $(0.61 \mathrm{~mm})$, a najmanju populacije Đerdap i Stara Planina $(0.58 \mathrm{~mm})$. Najmanja vrijednost de- 
Tablica 3. Statistička značajnost (p-vrijednost) efekta stabla unutar populacija (unutarpopulacijska varijabilnost) za analizirana svojstva po provenijencijama. Udio komponente varijance istog efekta na temelju analize svih provenijencija zajedno (zadnja kolona).

Table 3. Statistical significance (p-value) of trees nested within populations effect (i.e. within-population variability) for analyzed traits per provenance amd percentage of variance component of the same effect calculated by combined analysis of all provenances (the last column).

\begin{tabular}{|c|c|c|c|c|c|c|c|c|c|c|}
\hline \multirow{2}{*}{$\begin{array}{l}\text { Svojstvo/ } \\
\text { Trait }\end{array}$} & \multicolumn{9}{|c|}{ Unutar populacija/Within populations } & \multirow{2}{*}{$\begin{array}{c}\text { Komponenta } \\
\text { varijance / Variance } \\
\text { component (\%) }\end{array}$} \\
\hline & A & B & C & D & E & $\mathrm{F}$ & G & H & 1 & \\
\hline $\mathrm{FL}$ & $\mathrm{p}<0,01$ & $p<0,01$ & $\mathrm{p}<0,01$ & $\mathrm{p}<0,01$ & $p<0,01$ & $\mathrm{p}<0,01$ & $p<0,01$ & $\mathrm{p}<0,01$ & $p<0,01$ & 46,98 \\
\hline FW & $\mathrm{p}<0,01$ & $\mathrm{p}<0,01$ & $p<0,05$ & 0,89 & $\mathrm{p}<0,01$ & $p<0,01$ & $p<0,05$ & 0,50 & $\mathrm{p}<0,05$ & 41,21 \\
\hline FT & $\mathrm{p}<0,01$ & $\mathrm{p}<0,01$ & 0,41 & $\mathrm{p}<0,01$ & 0,14 & $\mathrm{p}<0,01$ & 0,25 & $\mathrm{p}<0,01$ & $\mathrm{p}<0,01$ & 45,23 \\
\hline FM & $\mathrm{p}<0,01$ & $\mathrm{p}<0,01$ & $\mathrm{p}<0,01$ & $\mathrm{p}<0,01$ & $\mathrm{p}<0,01$ & $p<0,01$ & $\mathrm{p}<0,01$ & $\mathrm{p}<0,01$ & $\mathrm{p}<0,01$ & 52,13 \\
\hline LOS & $\mathrm{p}<0,05$ & $\mathrm{p}<0,01$ & 0,37 & 0,41 & $\mathrm{p}<0,01$ & 0,015 & 0,68 & $p<0,01$ & $p<0,01$ & 47,12 \\
\hline WOS & 0,50 & 0,08 & 0,39 & $\mathrm{p}<0,01$ & 0,23 & $p<0,01$ & 0,27 & $p<0,01$ & 0,30 & 45,68 \\
\hline SL & $p<0,01$ & $\mathrm{p}<0,01$ & $p<0,01$ & $\mathrm{p}<0,01$ & $\mathrm{p}<0,01$ & $p<0,01$ & $p<0,01$ & $\mathrm{p}<0,01$ & $p<0,01$ & 40,15 \\
\hline SW & $\mathrm{p}<0,01$ & $\mathrm{p}<0,01$ & $p<0,05$ & 0,94 & $p<0,01$ & $p<0,01$ & $p<0,01$ & 0,26 & $p<0,01$ & 43,25 \\
\hline ST & $p<0,01$ & $p<0,01$ & 0,59 & $\mathrm{p}<0,01$ & $p<0,01$ & $p<0,01$ & 0,17 & 0,12 & $p<0,01$ & 51,16 \\
\hline SM & $p<0,01$ & $p<0,01$ & $p<0,01$ & $\mathrm{p}<0,01$ & $p<0,01$ & $p<0,01$ & $p<0,01$ & $\mathrm{p}<0,01$ & $p<0,01$ & 46,18 \\
\hline
\end{tabular}

Tablica 4. Pearson-ovi korelacijski koeficijenti između analiziranih svojstava (dijagonalno gore; statistički značajni koeficijenti naglašeni su debljim brojevima) i njihova statistička značajnost (p-vrijednosti; dijagonalno dolje; statistički značajne p-vrijednosti naglašene su crvenim brojevima). Table 4. Pearson correlation coefficients between analyzed traits (diagonal up; significant coeficients highlighted in bold) and their statistical significance (p-values; diagonal down; significant p-values highlighted in red).

\begin{tabular}{crrrrrrrrrrrr} 
& GERM & FL & FW & FT & FM & LOS & WOS & \multicolumn{1}{c}{ SL } & SW & ST & SM \\
GERM & & $-0,59$ & 0,17 & 0,34 & $-\mathbf{0 , 6 9}$ & $-\mathbf{0 , 7 3}$ & 0,53 & $-0,60$ & $-0,47$ & $-0,55$ & $-\mathbf{0 , 7 2}$ \\
FL & 0,092 & & 0,31 & 0,39 & 0,49 & 0,34 & $-0,47$ & $\mathbf{0 , 8 8}$ & 0,31 & 0,28 & 0,58 \\
FW & 0,656 & 0,416 & & $\mathbf{0 , 9 0}$ & 0,27 & $-0,55$ & 0,01 & 0,29 & 0,47 & 0,24 & 0,13 \\
FT & 0,377 & 0,296 & 0,001 & & 0,16 & $-0,59$ & 0,12 & 0,40 & 0,32 & 0,12 & 0,12 \\
FM & 0,038 & 0,177 & 0,480 & 0,679 & & 0,14 & $-0,25$ & $\mathbf{0 , 7 1}$ & $\mathbf{0 , 9 3}$ & $\mathbf{0 , 9 4}$ & $\mathbf{0 , 9 0}$ \\
LOS & 0,025 & 0,376 & 0,125 & 0,092 & 0,727 & & $-0,30$ & 0,22 & $-0,14$ & 0,00 & 0,33 \\
WOS & 0,143 & 0,202 & 0,980 & 0,759 & 0,525 & 0,438 & & $-0,31$ & $-0,22$ & $-0,14$ & $-0,08$ \\
SL & 0,087 & 0,002 & 0,447 & 0,287 & 0,031 & 0,577 & 0,415 & & 0,54 & 0,55 & $\mathbf{0 , 8 3}$ \\
SW & 0,207 & 0,411 & 0,199 & 0,398 & 0,000 & 0,723 & 0,571 & 0,130 & & $\mathbf{0 , 9 2}$ & $\mathbf{0 , 7 3}$ \\
ST & 0,129 & 0,465 & 0,534 & 0,756 & 0,000 & 0,998 & 0,724 & 0,124 & 0,000 & & $\mathbf{0 , 8 3}$ \\
SM & 0,029 & 0,101 & 0,734 & 0,755 & 0,001 & 0,381 & 0,843 & 0,006 & 0,026 & 0,005 &
\end{tabular}

bljine peteljke izmjerena je u populacijama Lipovica i Javor $(0.11 \mathrm{~mm})$, a najveća u populaciji Stara Planina ( 1.68 $\mathrm{mm})$. Koeficijent varijabilnosti bio je najveći kod populacije Javor (33.53\%), a najmanji kod populacije Đerdap (24.42\%).

Srednja vrijednost dužine sjemenke (SL) iznosila je 7.44 $\mathrm{mm}$. Najveća srednja vrijednost je utvrđena kod populacije Stara Planina $(7.92 \mathrm{~mm})$, a najmanja kod populacije Bešnjaja $(6.60 \mathrm{~mm})$. Najveća vrijednost dužine sjemenke izmjerena je kod populacije Jastrebac $(9.74 \mathrm{~mm})$, a najmanja kod populacije Fruška gora ( $3.75 \mathrm{~mm})$. Najmanji koeficijent varijabilnost imala je populacija Javor (6.17\%), a najveći populacija Jastrebac (13.76\%).

Srednja vrijednost širine sjemenke (SW) iznosila je 6.16 $\mathrm{mm}$. Najveću srednju vrijednost širine sjemenke imala je populacija Jastrebac $(6.68 \mathrm{~mm})$, a najmanju populacija Radan (5.85). Najveća vrijednost širine sjemenke izmjerena je kod populacije Jastrebac $(8.08 \mathrm{~mm})$, a najmanja kod populacije Lipovica $(4.18 \mathrm{~mm})$. Koeficijent varijabilnosti kretao se od 5.03\% kod populacije Đerdap do $12.01 \%$ kod populacije Jastrebac.

Srednja vrijednost debljine sjemenke (ST) iznosila je 4.83 $\mathrm{mm}$. Najveća srednja vrijednost debljine sjemenke utvrđena je kod populacije Jastrebac $(5.43 \mathrm{~mm})$, a najmanja kod populacije Radan $(4.62 \mathrm{~mm})$. Najveća vrijednost debljine sjemenke izmjerena je kod populacije Jastrebac $(6.30 \mathrm{~mm})$, a najmanja kod populacija Radan, Javor, Divčibare i Đerdap $(4.00 \mathrm{~mm})$. Najveća vrijednost koeficijenta varijabilnosti utvrđena je kod populacije Javor (13.28\%), a najmanja kod populacije Bešnjaja (9.06\%).

Srednja vrijednost mase sjemenke (SM) iznosila je $0.14 \mathrm{~g}$. Najveću srednju vrijednost mase sjemenke imala je populacija Jastrebac (0.17 g), a najmanju populacija Bešnjaja $(0.11 \mathrm{~g})$. Najveća vrijednost mase sjemenke izmjerena je kod populacije Jastrebac $(0.27 \mathrm{~g})$, a najmanja kod populacije Bešnjaja $(0.06 \mathrm{~g})$. Koeficijent varijabilnosti bio je najveći kod populacije Jastrebac (23.29\%), a najmanji kod populacije Stara Planina (16.14\%). 


\section{Varijabilnost unutar provenijencija i korelacije svojstava - Variability within provenances and correlations among traits}

REML metodom (Restricted Maximum Likelihood Method) utvrđen je udio zastupljenosti pojedinih istraživanih izvora varijabilnosti u ukupnoj varijanci (između populacija, između stabala unutar populacije, unutar stabala). Dobiveni rezultati pokazuju da je razina unutarpopulacijske varijabilnosti bila visoka, zauzimajući od $41 \%$ do $52 \%$ ukupne varijance (Tablica 3). Također, stabla unutar populacija signifikantno su se razlikovala s obzirom na većinu istraživanih morfoloških svojstava (Tablica 3).

Klijavost je u prosjeku bila statistički značajno negativno korelirana s masom ploda (FM), duljinom peteljke (LOS) i masom sjemenke (SM). Također, značajna pozitivna korelacija utvrđena je između širine i debljine ploda (FT-FW), mase ploda i svih dimenzija sjemenke kao i između mase i ostalih dimenzija sjemenke (Tablica 4).

\section{Varijacije između provenijencija - Among-provenance variation}

Na osnovi dobivenih rezultata analize varijance (ANOVA) može se zaključiti da su između istraživanih provenijencija utvrđene statistički značajne razlike, za sva analizirana morfološka svojstva izuzev za debljinu peteljke (WOS) (Tablica 5).

U pokušaju utvrđivanja obrasca u varijacijama istraživanih svojstava između provenijencija, proveli smo Pearson-ovu korelacijsku analizu između prosječnih vrijednosti provenijencija i klimatsko-geografskih varijabli njihovih izvornih sastojina (Tablica 6). Statistički značajne korelacije utvrđene su kod samo dva morfološka svojstva, debljine ploda (FT) i duljine peteljke (LOS). FT je bila signifikantno pozitivno korelirana s nadmorskom visinom (Elev) (Slika 2a), godišnjom sumom stupanj-dana ispod $0^{\circ} \mathrm{C}\left(\mathrm{DD} \_0\right)$ i prosječnom godišnjom količinom snijega (PAS) (Slika 2b). LOS je bila pozitvno korelirana s godišnjim omjerom temperature i količine oborina (AHM), a negativno korelirana s PAS varijablom (Tablica 6).

Signifikantni korelacijski odnosi između prosječnih vrijednosti debljine ploda i duljine peteljke provenijencija s nadmorskom visinom i ekološkim varijablama njihovih staništa pokazuju klinalni obrazac diferencijacije između provenijencija (Slika 2). Prosječna debljina ploda rasla je s porastom nadmorske visine provenijencija $(\mathrm{R}=0.69 ; \mathrm{p}=$ $0.04)$. Isti obrazac mogao se uočiti i iz odnosa prosječne debljine ploda s prosječnom godišnjom količinom snježne oborine $(\mathrm{R}=0.80 ; \mathrm{p}=0.01$; Slika $2 \mathrm{~b})$, kao i s godišnjom sumom stupanj dana $<0^{\circ} \mathrm{C}(\mathrm{R}=0.70 ; \mathrm{p}=0.04)$, što su evidentno varijable povezane s nadmorskom visinom staništa. Provenijencije s najviših nadmorskih visina (A-Javor i BRadan), a ujedno i sa najhladnijih staništa koje odlikuje
Tablica 5. Udio komponente varijance efekta provenijencija (varijabilnost između populacija) i njegova statistička značajnost za istraživana morfološka svojstva.

Table 5. Provenance effect variance component percentage (i,e, variability among populations) and its statistical significance for investigated morphological traits.

\begin{tabular}{ccc} 
& \multicolumn{2}{c}{ Efekt - Effect (\%) } \\
Svojstvo/Trait & $\begin{array}{c}\text { Populacija } \\
\text { Population }\end{array}$ & $\begin{array}{c}p \text {-vrijednost } \\
\text { p-value }\end{array}$ \\
FL & 9,62 & $<0,01$ \\
FW & 11,7 & $<0,01$ \\
FT & 6,58 & $<0,01$ \\
FM & 13,22 & $<0,01$ \\
LOS & 8,65 & $<0,01$ \\
WOS & 5,25 & 0,92 \\
SL & 11,26 & $<0,01$ \\
SW & 15,18 & $<0,01$ \\
ST & 10,23 & $<0,01$ \\
SM & 11,45 & $<0,01$ \\
FL & 9,25 & $<0,01$
\end{tabular}

najveća količina snježne oborine, imale su prosječno najdeblje plodove. Prosječna duljina peteljke provenijencija bila je također signifikantno korelirana s PAS varijablom, ali negativnog predznaka $(\mathrm{R}=-0.69 ; \mathrm{p}=0.04$; Tablica 6$)$. Dakle, u prosjeku su najkraće peteljke imale provenijencije čija se staništa odlikuju najvećom količinom snijega, dok je s opadanjem prosječne godišnje količine snijega u staništima rasla prosječna duljina peteljke. Prosječna duljina peteljke provenijencija bila je u pozitivnoj korelaciji s omjerom godišnje temperature i količine oborina njihovih staništa $(\mathrm{R}=0.71 ; \mathrm{p}=0.03)$. I ovi korelacijski odnosi ukazuju na klinalni obrazac diferencijacije provenijencija, povezan s nadmorskom visinom odnosno klimatskim varijablama koje su značajno povezane s nadmorskom visinom (količina snijega, odnos temperature i vlage staništa). Provenijencija Lipovica $(G)$ je odstupala od opisanih trendova i time bitno utjecala na smanjenje izračunatih koeficijenata korelacije (Slika 2). Izuzimanjem te provenijencije iz analiza, kvadratni koeficijent korelacije $\left(\mathrm{R}^{2}\right)$ između prosječne debljine ploda i nadmorske visine porastao je na 0.80 (Slika 2a), a između prosječne debljine ploda i PAS na 0.89 (Slika 2b). Dakle, klinalni obrazac diferencijacije provenijencija bio bi još značajniji i izraženiji da provenijencija Lipovica nije uzorkovana.

\section{RASPRAVA I ZAKLJUČCI DISCUSSION AND CONCLUSIONS}

Dobiveni rezultati ukazuju na postojanje značajne razine fenotipske varijabilnosti provenijencija divlje trešnje u Srbiji, s obzirom na istraživana svojstva plodova (Tablica 2). Visoka razina fenotipske raznolikosti plodova i sjemena divlje trešnje u ovom dijelu Europe je potvrđena i drugim 
Tablica 6. Statistička značajnost (p-vrijednosti) Pearson-ovih korelacijskih koeficijenata između populacijskih prosjeka za istraživana svojstva i klimatskih (geografskih) varijabli njihovih izvornih sastojina.

Table 6. Statistical significance (p-values) of Pearson's correlation coefficients between analyzed trait provenance means and climate (geographic) variables of their stands of origin.

$\begin{array}{ccccccccccccc} & \text { GERM } & \text { FL } & \text { FW } & \text { FT } & \text { FM } & \text { LOS } & \text { WOS } & \text { SL } & \text { SW } & \text { ST } & \text { SM } \\ \text { Lat } & 0,416 & 0,400 & 0,572 & 0,124 & 0,809 & 0,414 & 0,875 & 0,406 & 0,725 & 0,857 & 0,848 \\ \text { Long } & 0,657 & 0,624 & 0,428 & 0,529 & 0,765 & 0,181 & 0,409 & 0,747 & 0,633 & 0,599 & 0,642 \\ \text { Elev } & 0,358 & 0,418 & 0,221 & 0,040 & 0,768 & 0,095 & 0,560 & 0,346 & 0,514 & 0,696 & 0,968 \\ \text { MAT } & 0,387 & 0,560 & 0,331 & 0,115 & 0,811 & 0,110 & 0,366 & 0,531 & 0,516 & 0,706 & 0,849 \\ \text { MWMT } & 0,340 & 0,556 & 0,325 & 0,088 & 0,796 & 0,083 & 0,501 & 0,460 & 0,518 & 0,708 & 0,921 \\ \text { MCMT } & 0,318 & 0,689 & 0,332 & 0,127 & 0,890 & 0,072 & 0,406 & 0,621 & 0,563 & 0,720 & 0,780 \\ \text { TD } & 0,407 & 0,409 & 0,350 & 0,067 & 0,677 & 0,130 & 0,683 & 0,292 & 0,484 & 0,708 & 0,872 \\ \text { MAP } & 0,466 & 0,769 & 0,108 & 0,055 & 0,607 & 0,054 & 0,910 & 0,351 & 0,323 & 0,677 & 0,768 \\ \text { MSP } & 0,651 & 0,953 & 0,312 & 0,300 & 0,681 & 0,138 & 0,642 & 0,573 & 0,387 & 0,789 & 0,938 \\ \text { AHM } & 0,335 & 0,704 & 0,179 & 0,052 & 0,693 & 0,032 & 0,696 & 0,378 & 0,384 & 0,665 & 0,922 \\ \text { SHM } & 0,401 & 0,865 & 0,307 & 0,152 & 0,733 & 0,051 & 0,500 & 0,512 & 0,402 & 0,729 & 0,939 \\ \text { DD_0 } & 0,228 & 0,550 & 0,171 & 0,038 & 0,910 & 0,085 & 0,541 & 0,626 & 0,740 & 0,949 & 0,684 \\ \text { DD5 } & 0,416 & 0,582 & 0,385 & 0,145 & 0,769 & 0,110 & 0,353 & 0,515 & 0,491 & 0,665 & 0,885 \\ \text { DD_18 } & 0,356 & 0,542 & 0,268 & 0,087 & 0,863 & 0,101 & 0,374 & 0,543 & 0,548 & 0,754 & 0,810 \\ \text { DD18 } & 0,431 & 0,677 & 0,515 & 0,225 & 0,766 & 0,120 & 0,346 & 0,574 & 0,496 & 0,650 & 0,867 \\ \text { NFFD } & 0,362 & 0,698 & 0,450 & 0,197 & 0,886 & 0,108 & 0,379 & 0,665 & 0,592 & 0,694 & 0,777 \\ \text { bFFP } & 0,355 & 0,679 & 0,459 & 0,174 & 0,782 & 0,086 & 0,502 & 0,583 & 0,518 & 0,626 & 0,882 \\ \text { eFFP } & 0,427 & 0,787 & 0,603 & 0,334 & 0,877 & 0,135 & 0,296 & 0,755 & 0,596 & 0,674 & 0,733 \\ \text { FFP } & 0,384 & 0,725 & 0,518 & 0,236 & 0,823 & 0,104 & 0,401 & 0,656 & 0,550 & 0,645 & 0,814 \\ \text { PAS } & 0,265 & 0,510 & 0,068 & 0,010 & 0,850 & 0,041 & 0,597 & 0,449 & 0,481 & 0,780 & 0,890 \\ \text { CMD } & 0,534 & 0,615 & 0,265 & 0,120 & 0,712 & 0,106 & 0,386 & 0,350 & 0,429 & 0,789 & 0,964\end{array}$

Lat - zemljopisna širina; Long - zemljopisna dužina; Elev - nadmorska visina; MAT - prosječna godišnja temperatura; MWMT - srednja temperatura srpnja; MCMT srednja temperatura siječnja; TD - indeks kontinentalnosti; MAP - godišnja količina oborina; MSP - količina oborina u ljetnom razdoblju; AHM - godišnji omjer temperature i oborina; SHM - ljetni omjer temperature i oborina; DD_0 - suma stupanj-dana ispod $0{ }^{\circ} \mathrm{C}$; DD5 - suma stupanj-dana $>5^{\circ} \mathrm{C}$; DD_18 - suma stupanj-dana $<18^{\circ} \mathrm{C}$; DD18 - suma stupanj-dana $>18^{\circ} \mathrm{C}$; NFFD - broj dana bez mraza; bFFP - početak razdoblja bez mraza; eFFP - završetak razdoblja bez mraza; PAS - količina snježne oborine; CMD - Hargreaves-ov indeks deficita vlage

Lat - latitude; Long - longitude; Elev - elevation; MAT - mean annual temperature; MWMT - mean July temperature; MCMT - mean January temperature; TD - continentality index; MAP - mean annual precipitation; MSP - mean summer precipitation; AHM - annual heat-to moisture index; SHM - summer heat-to-moisture index; DD_0 - sum of degree-days $\angle 0^{\circ} \mathrm{C}$; DD5 - sum of degree-days $>5^{\circ} \mathrm{C}$; DD_18 - sum of degree-days $<18^{\circ} \mathrm{C}$; DD 18 - sum of degree-days $>18^{\circ} \mathrm{C}$; NFFD - number of frost free days; bFFP - beginning of frost free period; eFFP - end of frost free period; PAS - precipitation as snow; CMD - climate moisture deficit
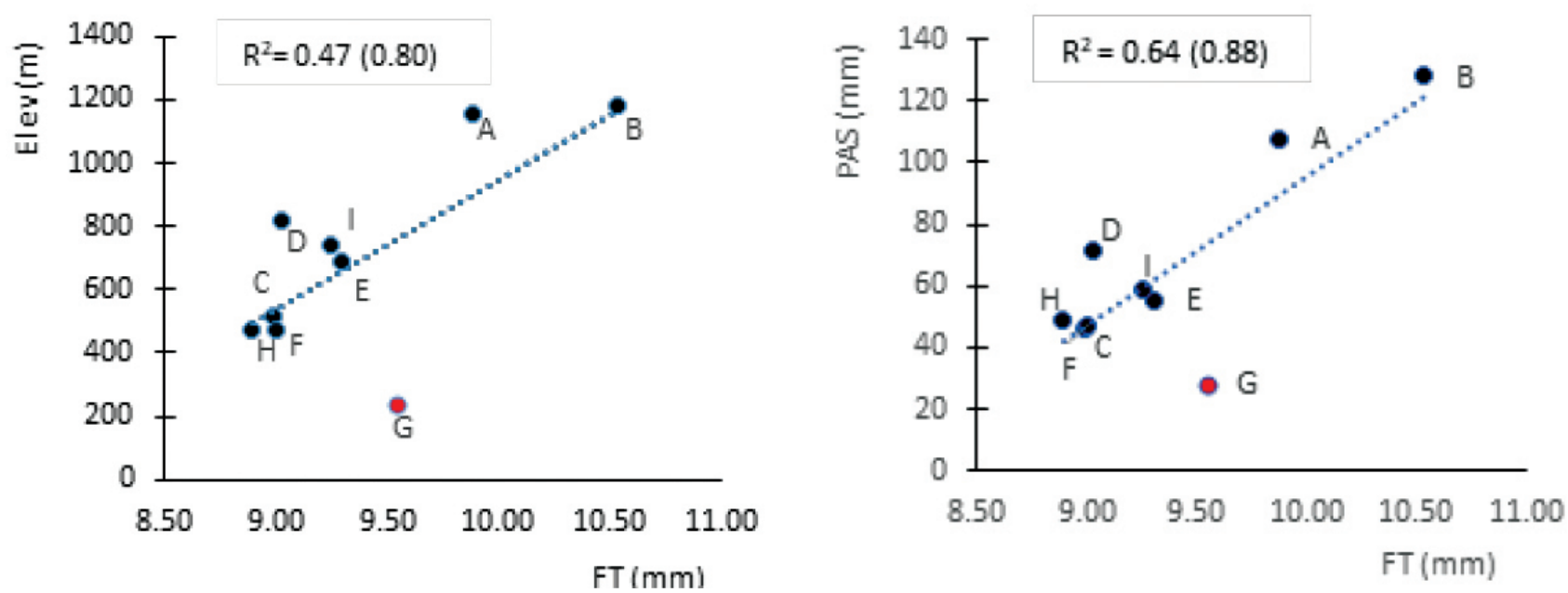

Slika 2. Odnos prosječne debljine ploda (FT) i: a) nadmorske visine (Elev) provenijencija; b) količine snježne oborine (PAS) u izvornim sastojinama. Provenijencija Lipovica (G) je bitno odstupala od trenda smanjujući koeficijente korelacija (u zagradama navedeni R2 bez provenijencije G).

Figure 2. Correlation between provenance mean fruit thickness (FT) and: a) elevation (Elev) at the stands of origin; b) precipitation as snow (PAS) at the stands of origin. Provenance Lipovica (G) means were outliers thus decreasing correlation coefficients (in brackets are shown R2 when provenance G were omitted from the calculations). 
istraživanjima (Ballian 2000; Ballian i Čabaravdić 2007; Ballian i sur. 2012; Mratinić i sur. 2012; Ballian i MujagićPašić 2013). Kao najvarijabilnije svojstvo istakla se debljina peteljke (WOS), dok se najmanje varijabilnim pokazala širina ploda $(\mathrm{FW})$. Prosječna vrijednost dužine ploda $(\mathrm{FL}=$ $10.62 \mathrm{~mm}$ ) je približna prosječnim vrijednostima provenijencija divlje trešnje u Bosni i Hercegovini (Balian i sur. 2012). Isti slučaj je i sa širinom ploda $(F W=9.94 \mathrm{~mm})$, debljinom ploda $(\mathrm{FT}=9.38 \mathrm{~mm})$, dužinom $(\mathrm{LOS}=39.36$ $\mathrm{mm}$ ) i debljinom $($ WOS $=0.59 \mathrm{~mm}$ ) peteljke ploda (Balian i dr. 2012). Dobivene prosječne vrijednosti za morfološke karakteristike sjemena: dužina sjemenke $(\mathrm{SL}=7.44 \mathrm{~mm})$, širina sjemenke ( $\mathrm{SW}=6.16 \mathrm{~mm}$ ) i debljina sjemenke (ST $=4.83 \mathrm{~mm}$ ) su također približne vrijednostima provenijencija u Bosni i Hercegovini (Ballian 2000; Ballian i Čabaravdić 2007; Ballian i sur. 2012). Rezultati prethodnih istraživanja divlje trešnje u Srbiji također su pokazali slične vrijednosti za dužinu, širinu i masu ploda, te dužinu, širinu i masu sjemenke (Mratinić i sur. 2012). Sličan raspon vrijednosti mase ploda (od 0.76 do $2.11 \mathrm{~g}$ ) uočen je i kod turskih provenijencija (Karlidag i sur. 2009).

Rezultati analize varijance (ANOVA) ukazuju na postojanje statistički značajnih razlika kako unutar tako i između provenijencija (Tablice 3, 5). Raščlanjivanjem ukupne varijance na pojedine komponente, utvrđeno je da je komponenta varijabilnosti unutar provenijencija bila znatno veća od varijabilnosti između provenijencija. Pojava visoke razine unutarpopulacijske varijabilnosti karakteristična je za većinu vrsta šumskog drveća, a može se objasniti migracijama gena (prirodnim putem, ali i ljudskim djelovanjem), kao i velikim utjecajem mikrostanišnih varijacija na morfološka svojstva (White i sur. 2007).

Iako je komponenta varijance uzrokovana razlikama između provenijencija bila manja od varijabilnosti unutar provenijencija, ona je ipak bila statistički značajna za većinu analiziranih svojstava (Tablica 5). Korelacijska analiza prosječnih vrijednosti svojstava s klimatsko-geografskim varijablima provenijencija, ukazala je na korisnost širine ploda (FT) i duljine peteljke (LOS) kao alata za istraživanje obrasca razlika između provenijencija (Tablica 6). Velik broj dosadašnjih istraživanja nije pokazao geografski obrazac diferencijacije provenijencija divlje trešnje u ovom dijelu Europe, ali nije detektiran niti ekološki uvjetovan obrazac razlika između provenijencija (Ballian 2000; Mikić 2007; Ballian i Čabaravdić 2007; Ballian i sur. 2012; Mratinić i sur. 2012; Ballian i Mujagić-Pašić 2013; Rakonjac i sur. 2014; Popović i Kerkez 2016). Nemogućnost determinacije obrasca geografske diferencijacije provenijencija autori su uglavnom objasnili efektima migracija gena i favoriziranja stranooplodnje (Rakonjac i sur. 2014), ili izostankom adaptacije na specifične stanišne uvjete zbog kasne i relativno brze postglacijalne kolonizacije Europe (Schirone i Spada 2000). Za razliku od spomenutih, ovo istraživanje ukazuje na ekološki uvjetovan obrazac diferencijacije provenijencija. Naime, rezultati korelacijske analize otkrili su klinalni obrazac razlika između provenijencija, povezan s nadmorskom visinom is njom koreliranim klimatskim varijablama izvornih staništa (Slika 2, Tablica 6). Također, utvrđeni obrazac ukazuje na genetsku diferencijaciju provenijencija tj. na mogućnost da su se provenijencije genetski izdiferencirale putem prirodne selekcije. Međutim, ovim istraživanjem nije bilo moguće razlučiti da li obrazac pokazuje genetske ili samo okolišne razlike između provenijencija, jer su plodovi uzorkovani u prirodnim populacijama. Za konačnu potvrdu genetske diferencijacije trebalo bi analizirati ova fenotipska svojstva u pokusnim nasadima (testovima provenijencija). Obrazac klinalne diferencijacije provenijencija divlje trešnje za fenološka svojstva s obzirom na nadmorsku visinu utvrdili su Díaz i Merlo (2008), dok su Miljković i sur. (2019) utvrdili korelaciju nadmorske visine s morfološkim svojstvima lista. Istraživanje Miljković i sur. (2019), zajedno s našim, ukazuje da su prirodne populacije divlje trešnje u ovom dijelu Europe vjerojatno genetski izdiferencirane pod utjecajem okolišnih varijacija staništa povezanih s razlikama u nadmorskoj visini.

Ugroženost divlje trešnje na europskoj razini temelji se na njenom disjunktnom arealu zbog kojeg se smatra rijetkom. Prirodna obnova divlje trešnje je slaba, ponajviše u prebornim šumama u kojima se favoriziraju skiofitne vrste (Jarni i sur. 2012). Uz to, bitnu ulogu u njenom otežanom obnavljanju ima ispaša divljači i slaba konkurentnost u odnosu na druge vrste, ponajprije obične bukve. Zbog navedenih razloga, kao i zbog ekonomske i ekološke važnosti, trebalo bi umjetno potpomagati obnavljanje divlje trešnje (Stjepanović 2012). Važnost pravilnog izbora reprodukcijskog materijala se, uz pravilne uzgojne zahvate, smatra glavnim preduvjetom za ostvarivanje maksimalne dobiti šumarske proizvodnje (Kingswell 1998; Coello i sur. 2013). Međutim, mogućnost genetske diferencijacije provenijencija nalaže potrebu opreza pri izboru reprodukcijskog materijala za potpomognutu obnovu ove vrste. Smatramo da rezultati našeg istraživanja daju temelj za preporuku sjemenske rajonizacije areala divlje trešnje u Srbiji s obzirom na nadmorsku visinu.

Za potrebe šumarstva sadnice divlje trešnje proizvode se generativnim načinom, zbog čega su osobine sjemena jedan od ključnih faktora kvalitetne proizvodnje šumskog reprodukcijskog materijala. Klijavost je svakako bitno svojstvo kvalitete sjemena. Prosječna klijavost provenijencija bila je statistički značajno korelirana s prosječnom masom ploda i sjemenke, ali i s prosječnom duljinom peteljke (Tablica 4). Iznenađuje što je korelacija između klijavosti i mase ploda odnosno sjemenke bila negativna, tj. da su provenijencije prosječno sitnijeg sjemena pokazale prosječno veću klijavost. Većina istraživanja na šumskom drveću pokazala su da je masa sjemena pozitivno korelirana s klijavošću od- 
nosno da u prosjeku krupnije sjeme pokazuje bržu i veću klijavost (Seiwa 2000; Das i sur. 2016). Međutim, postoje i rijetka izvješća u kojima nije potvrđena pozitivna uloga mase sjemena za uspješnost klijanja (Delgado i sur. 2001). Divlja trešnja pripada skupini drveća koje odlikuje izražena dormantnost sjemena (Çetinbaş i Koyuncu 2006) i varijacije u dormantnosti sjemena između različitih provenijencija (Esen i sur. 2006). Stoga, postoji mogućnost da su se provenijencije prosječno krupnijeg sjemena odlikovale i višom razinom dormantnosti, tj. da je njihovo sjeme „preležalo " još jednu vegetacijsku periodu. Time bi se mogao objasniti negativni odnos proječne mase i klijavosti sjemena u ovom istraživanju.

U smislu očuvanja i ciljanog korištenja genofonda divlje trešnje na nekom području, najprije je potrebno upoznati njenu genetsku raznolikost i strukturu. Do sada su već dokazane genetske različitosti između populacija iz središnjeg i jugoistočnog dijela Europe (Russell 2003). S obzirom na scenarije promjene klime potrebno je istražiti genetski potencijal populacija iz rubnih dijelova areala, koje su već izložene stresnijim okolišnim uvjetima u usporedbi s populacijama iz središnjeg dijela. Također, postoje naznake da se populacije iz južnog dijela areala odlikuju visokim i specifičnim genetskim diverzitetom (Ganopoulos i sur. 2011). Zbog toga je nužno više pzornosti usmjeriti na istraživanje genetske strukture i potencijala divlje trešnje u ovom dijelu Europe, posebno kroz osnivanje klonskih testova, testova provenijencija i testova familija srodnika, kao i kroz promociju održivog gospodarenja genofondom ove vrste $(\mathrm{Ru}-$ ssell 2003).

Rezultalti ovog istraživanja pokazali su visoke razine unutarpopulacijske varijabilnosti, ali i diferencijaciju između provenijencija. Identificiran je ekoklinalni obrazac diferencijacije provenijencija, povezan sa stanišnim varijacijama s obzirom na nadmorsku visinu. Ovo ukazuje na genetsku diferenciranost provenijencija divlje trešnje u Srbiji. Međutim, to se ovim istraživanjem nije moglo potvrditi, jer se temeljilo na biljnim uzorcima iz prirodnih populacija. Mogućnost genetske diferencijacije provenijencija s obzirom na nadmorsku visinu daje temelj preporuci vertikalne sjemenske zonacije areala divlje trešnje u Srbiji, kao i sukladnog korištenja njenog reprodukcijskog materijala u potpomognutoj obnovi. Međutim, da li su svojstva na temelju kojih je utvrđen ovaj obrazac diferencijacije provenijencija adaptivno vrijedna, tj. jesu li debljina ploda i duljina peteljke korelirane s adaptiranošću provenijencija divlje trešnje na lokalne stanišne prilike, ostaje otvoreno pitanje. Kako bi rezultati bili jasniji, neophodno je istražiti genetsku raznolikost i strukturu prirodnih populacija primjenom analiza raznovrsnih fenotipskih svojstava u posebno dizajniranim pokusnim nasadima (npr. testovima provenijencija) kao i analizama prikladnih DNA markera.

\section{LITERATURA}

\section{REFERENCES}

- Avramidou, E.V., I. V., Ganopoulos, F. A., Aravanopoulos, 2010: DNA fingerprinting of elite Greek wild cherry (Prunus avium L.) genotypes using microsatellite markers, FORESTRY 83 (5): 527-533.

- Avramidou, E.V., I.V., Ganopoulos, A.G., Doulis, A.S., Tsaftaris, F.A., Aravanopoulos, 2015: Beyond population genetics: natural epigenetic variation in wild cherry (Prunus avium). Tree genetics \& genomes, 11(5): 95.

- Ballian, D., 2000: Početna istraživanja varijabilnosti morfoloških svojstava sjemena divlje trešnje (Prunus avium L.), Sumar. list, 124 (5-6): 271-278.

- Ballian, D., 2004: Varijabilnost mikrosatelitne DNK u populacijama divlje trešnje (Prunus avium L.) iz središnje Bosne, Sumar. list, 128 (11-12): 649-653.

- Ballian, D., A. Čabaravdić, 2007: Neki korelacijski odnosi između svojstava pupova, cvijeta i sjemena divlje trešnje (Prunus avium L.) iz populacije Mrkovići, Works of the Faculty of Forestry University of Sarajevo, 1:29 - 38.

- Ballian, D., F. Bogunić, A. Čabaravdić, S. Pekeč, J. Franjić, 2012: Population differentiation in the wild cherry (Prunus avium L.) in Bosnia and Herzegovina, Period. Boil., 114 (1): 43-54.

- Ballian, D., A., Mujagić-Pašić, 2013: Morphological variability of the fruit and seed of wild cherry (Prunus avium L.) in a part of its natural distribution in Bosnia and Herzegovina. Biologica Nyssana, 4 (1-2).

- Banković, S., M., Medarević, D., Pantić, N., Petrović, 2008: National Forest Inventory of the Republic of Serbia: the forest fund of the Republic of Serbia, Ministry of Agriculture, Forestry and Water Management of the Republic of Serbia, the Forest Administration, Belgrade: p. 57.

- Barać, G., V., Ognjanov, M., Ljubojević, D., Dorić, J., Dulić, M. Miodragović, 2015: Assessment of biodiversity among cherry species using SSR molecular markers. Applications of Molecular Markers in Plant Genome Analysis and Breeding: 165-182.

- Bogdan, S., 2009: Genetika s oplemenjivanjem drveća i grmlja (interna skripta). Šumarski fakultet Sveučilišta u Zagrebu, 1-207.

- CABI, 2013: Encyclopedia of Forest Trees, p. 401-403.

- Campoy, J.A., E., Lerigoleur-Balsemin, H., Christmann, R., Beauvieux, N., Girollet, J., Quero-García, E., Dirlewanger, T., Barreneche, 2016: Genetic diversity, linkage disequilibrium, population structure and construction of a core collection of Prunus avium L. landraces and bred cultivars. BMC plant biology, 16(1), p.49.

- Çetinbaş, M., F., Koyuncu, 2006: Improving germination of Prunus avium L. seeds by gibberellic acid, potassium nitrate and THIOUREA. Hort Science 33 (3): 119-123.

- Coello J., J., Becquey, P., Gonin, P., Ortisset Jean, V., Desombre, T., Baiges, M., Piqué, 2013: Ecology and silviculture of the main valuable broadleaved species in the Pyrenean area and neighbouring regions.Government of Catalonia, Ministry of Agriculture, Livestock, Fisheries, Food and Natural Environment - Catalan Forest Ownership Centre, Santa Perpètua de Mogoda (Spain), (13-20).

- Das, M.C., A.J. Nath, P. Singnar, A.K., Das, 2016: Effect of fruit mass on germination and seedling characteristics of a tropical climbing bamboo melocalamus compactiflorus. J Plant Chem and Ecophysiol 1 (1): 1003.

- Delgado, J.A., J.M., Serrano, F., López, F.J., Acosta, 2001: Heat shock, mass-dependent germination, and seed yield as related 
components of fitness in cistus ladanifer. Environmental and Experimental Botany 46 (1): 11-20.

- De Rogatis, A., D., Ferrazzini, F., Ducci, S., Guerri, S., Carnevale, P., Belletti, 2013: Genetic variation in Italian wild cherry (Prunus avium L.) as characterized by nSSR markers. Forestry 86: 391400.

- Díaz, R., E., Merlo, 2008: Genetic variation in reproductive traits in a clonal seed orchard of Prunus avium in Northern Spain. Silvae Genetica 57 (1-6): 110-18.

- Ducci, F., F., Santi, 1997: The distribution of clones in managed and unmanaged populations of wild cherry (Prunus avium), Canadian Journal of Forest Research 27: 1998-2004.

- Ducci, F., B., De Cuyper, A., De Rogatis, J., Dufour, F., Santi, 2013: Wild cherry breeding (Prunus avium L.). In forest tree breeding in Europe. Springer, Dordrecht. 463-511.

- El-Kassaby Y.A., 1992: Domestication and genetic diversityshould we be concerned?, For Chron. 68: 687-700.

- Esen, D., Y., Oktay, C., Emrah, K., Semsettin, K., Cigdem, 2006: Effects of different pretreatments on the germination of different wild cherry (Prunus avium L.) seed sources. Pakistan Journal of Botany 38 (3): 735-743.

- Frascaria, N., Santi, F., Gouyon, P. H. (1993): Genetic differentiation within and among populations of chestnut (Castanea sativa Mill.) and wild cherry (Prunus avium L.)., Genetical Society of Great Britain: 634-644.

- Ganopoulos, I.V., E., Avramidou, D.A., Fasoula, G., Diamantidisand, F.A., Aravanopoulos, 2010: Assessing inter- and intracultivar variation in Greek Prunus avium by SSR markers. Plant Genetic Resources: Characterization and Utilization 8 (3): $242-$ 248.

- Ganopoulos, I., F.A., Aravanopoulos, A., Argiriou, A., Kalivas, A., Tsaftaris, 2011: Is the genetic diversity of small scattered forest tree populations at the southern limits of their range more prone to stochastic events? A wild cherry case study by microsatellite-based markers, Tree Genetics \& Genomes 7: 1299-1313.

- Ganopoulos, I., F.A., Aravanopoulos, A., Tsaftaris, 2013: Genetic differentiation and gene flow between wild and cultivated Prunus avium: An analysis of molecular genetic evidence at a regional scale. Plant Biosystems 147 (3): 1-8.

- Harrell F.E. Jr. et al. (2019): Hmisc: Harrell Miscellaneous. R package version 4.3-0. https://CRAN.R-project.org/ package $=$ Hmisc

- Ivanovych, Y., R., Volkov, 2018: Genetic relatedness of sweet cherry (Prunus avium L.) cultivars from Ukraine determined by microsatellite markers. The Journal of Horticultural Science and Biotechnology, 93(1), pp.64-72.

- Jagodić, A., 2014: Program genetičke konzervacije šumskih voćkarica na području ŠG „Visočnik”. Master rad. Šumarski fakultet, Univerzitet u Beogradu, Beograd (53-66).

- Jarni, K., B., Cuyper, R., Brus, 2012: Genetic variability of wild cherry (Prunus avium L.) seed stands in slovenia as revealed by nuclear microsatellite loci. Plos one 7: 1-5.

- Jovković, R., 1999: Potencijalna vrednost trešnje vrapčare (Prunus avium L.) u proizvodnji biološko visoko vredne hrane, Magistraska teza, Šumarski fakultet, Beograd.

- Karlidag, H., S., Ercisli, M., Sengul, M., Tosun, 2009: Physicochemical diversity in fruits of wild-growing sweet cherries (Prunus avium L.). Biotechnology \& Biotechnological Equipment, 23(3), 1325-1329.
- Katičić Bogdan, I., K., Švorinić, S., Bogdan, D., Kajba, 2015: Generativna i vegetativna aktivnost divlje trešnje (Prunus avium L.) u klonskoj sjemenskoj plantaži. Sumar list, 139 (7-8), 339-348.

- Kingswell, G., 1998: Tree Biotehnology: Toward the Milenium, ed. Davey M. R., Alderson P. G., Lowe K. C., Power J.B.,School of Biological Sciencies, University of Nottingham, UK, (23-29);

- Krüssman, G., 1978: Handbuch der Laubghözle. Berlin und Hamburg, Bd I-II.

- Lacis, G., I., Rashal, S., Ruisa, V., Trajkovski, A.F., Iezzoni, 2009: Assessment of genetic diversity of Latvian and Swedish sweet cherry (Prunus avium L.) genetic resources collections by using SSR (microsatellite) markers. Scientia Horticulturae 121: 451457.

- Mikić, T. 2007: Analiza morfoloških parametara lista divlje trešnje (Prunus avium L.) u Bosni i Hercegovini, Doktorska disertacija, Šumarski fakultet, Univerzitet u Banja Luci, Banja Luka, (1-118)

- Milatović D., M., Nikolić, N., Miletić, 2015: Trešnja i višnja, ured. Veličković M., Ognjanov V., Naučno voćarsko društvo Srbije, Čačak, (19-128)

- Miljković, D., M., Stefanović, S., Orlović, M., Stanković Neđić, L., Kesić, S., Stojnić, 2019: Wild cherry (Prunus avium L.) leaf shape and size variations in natural populations at different elevations. Alpine Botany 129 (2): 163-74.

- Mratinić E., M., Fotirić Akšić, R., Jovković, 2012: Analysis of wild sweet cherry (Prunus avium L.) germplasm diversity in southeast Serbia. Genetika, 44(2), 259-268.

- Mratinić, E., M.,Kojić, 1998: Samonikle vrste voćaka Srbije, ured. Mišić P., Tucović A., Šoškić M., Institut za istraživanja u poljoprivredi, Beograd: 5-366.

- OECD, 2014: Rules and Regulations of the OECD Forest Seed and Plant Scheme.

- Piotto B., G., Bartolini, F., Bussotti, A.A., Calderón, I., García Chessa, C., Ciccarese , L., Ciccarese, R., Crosti, A., Cullum Di Noi, P., García-Fayos, M., Lambardi, M., Lisci, S., Lucci, S., Melini, J.C.M., Reinoso, S., Murranca, G., Nieddu, E., Pacini, G., Pagni, M., Patumi, F., Pérez García, C., Piccini, M., Rossetto, G., Tranne, T., Tylkowski, 2003: Seed propagation of mediterranean trees and shrubs, "Fact sheets on the propagation of mediteerranean trees and shrubs from seed", ed. Piotto B., Di Noi A., APAT - Agency for the protection of the environment and for technical services, Italy, Roma (42).

- Popović, V., I., Kerkez, 2016: Varijabilnost populacija divlje trešnje (Prunus avium L.) u Srbiji prema morfološkim svojstvima listova. Sumar list, 7-8, 347-355.

- Rakonjac, V., 1993: Genetiĉka varijabilnost populacije trešnje (Prunus avium L.) Kraljevačkog regiona, Magistraska teza, Poljoprivredni fakultet, Beograd.

- Rakonjac, V., E. Mratinić, R. Jovković, M. Fotirić Akšić, 2014: Analysis of morphological variability in wild cherry (Prunus avium L.) genetic resources from central Serbia, J. Agr. Sci. Tech., 16: 151-162.

- Russell, K., 2003: EUFORGEN Technical guidelines for genetic conservation and use for wild cherry (Prunus avium). International Plant Genetic Resources Institute, Rome, Italy. p. 6.

- Schirone, B., F. Spada, 2000: Some remarks on the conservation of genetic resources of Mediterranean oaks. U: S. Borelli, M. C. Varela (ur.): Mediterranean Oaks Network, Report of the first meeting, 21-26, Antalya. 
- Seiwa, K., 2000: Effects of seed size and emergence time on tree seedling establishment: Importance of developmental constraints. Oecologia 123 (2): 208-215.

- Stjepanović, S., 2012: Pokazatelji kvaliteta jednogodišnjih sadnica divlje trešnje (Prunus avium L.), Master rad. Šumarski fakulet, Univerzitet u Beogradu, Beograd (8-45).

- Sweet, G.B., 1995: Seed orchards in development, Tree Physiology 15: 527-530

- Tančeva Crmarić , O., S. Štambuk, Z. Šatović, D. Kajba 2011: Genotipska raznolikost divlje trešnje (Prunus avium L.) u dijelu prirodne rasprostranjenosti u Hrvatskoj, Sumars list, 130 (1112): 543-555.

- Tomić, Z., 2004: Šumarska fitocenologija, Šumarski fakultet Univerziteta u Beogradu, Beograd, (133-174).

- Turet-Sayar, M., A., Turkec, T., Demir, 2012: Identification of sweet cherry cultivars (Prunus avium L.) and analysis of their genetic relationship using microsatellite DNA Fingerprinting. Journal of Agricultural Science 4 (8): 134-140.

- Vavilov, N.I., 1935: Teoretičerskie osnovi selekcii rastenij. Gos izdat kolhoznoj i sovhoznoj literaturi, Moskva-Leningrad.

- Žukovsky, P.M., 1965: Main gene centers of cultivated plants and their wild relation within the territory of the USSR. Euphytica, p 14.

- Wang, T., A., Hamann, D.L., Spittlehouse, T.Q., Murdock, 2012: ClimateWNA - Highresolution spatial climate data for western North America. Journal of Applied Meteorology and Climatology, 51: 16-29.

- Welk, E., D., de Rigo, G., Caudullo, 2016: Prunus avium in Europe: distribution, habitat, usage and threats. In: San-MiguelAyanz, J., de Rigo, D., Caudullo, G., Houston Durrant, T., Mauri, A. (Eds.), European Atlas of Forest Tree Species. Publ. Off. EU, Luxembourg, pp. e01491d.

\section{SUMIMARY}

Natural wild cherry populations in Serbia are a part of the southern border of this valuable forest tree species distribution range. The survival of these marginal provenances in Serbia as well as in the wider region is threatened by climate change, small population sizes, low competitiveness, etc. Therefore, it is recommended to artificially assist population regeneration while increasing their genetic diversity. Although knowledge of the amount and pattern of the specie's genetic diversity is a prerequisite for its effective conservation and use, related research in the region is scarce. The main goal of this study was to determine the amount and pattern of phenotypic variability of natural wild cherry populations in Serbia. Possible link between revealed pattern of phenotypic variability and genetic differentiation of the provenances was discussed.

Fruits were collected in nine natural populations. Ten morphological traits of the fruits were measured, and average germination rate of the provenances was assessed. The least variable trait was the fruit width $(\mathrm{CV}=6.2 \%)$, while the most variable trait was the petiole thickness $(\mathrm{CV}=29.4 \%)$. Analysis of variance revealed significant among-provenance variation for investigated fruit characteristics $(p<0.01 ; \alpha=0.05)$, except for the petiole thickness $(\mathrm{p}=0.92)$. Although variability among provenances was significant, the level of within-population variability was much higher (41.2-52.1\%) than among-provenance differentiation (5.3-15.2\%). The pattern of among-provenance variation was determined by a correlation analysis between provenance mean values and their climatic-geographical variables, whereby fruit thickness and petiole length proved to be useful diagnostic traits. Mean fruit thickness was significantly and positively correlated with altitude $(R=0.69 ; \mathrm{p}=0.04)$, annual precipitation as snow $(\mathrm{R}=0.80 ; \mathrm{p}=0.01)$, and annual degree-days below $\left.0{ }^{\circ} \mathrm{C}(\mathrm{R}=0.70) ; \mathrm{p}=0.04\right)$. The average petiole length was significantly and negatively correlated with the annual precipitation as snow $(R=-0.69 ; \mathrm{p}=0.04)$, while it was positively correlated with annual heat to moisture index $(\mathrm{R}=0.71 ; \mathrm{p}=0.03)$. The results revealed an ecoclinal pattern of phenotypic differentiation among the provenances due to their habitat's altitude and other ecological variables closely related to altitude.

Although this study basically dealt with phenotypic variability of wild cherry fruits originating from natural populations, the results indicate likelihood for genetic differentiation of the provenances due to altitude. This likelihood provides the basis for recommending vertical seed zonation, as well as congruent use of reproductive material for assisted restoration of wild cherry populations in Serbia. However, to confirm this presumption of ecoclinal pattern of genetic differentiation, it is necessary to conduct analyses of various phenotypic traits in common garden experiments (e.g. provenance trials) as well as analyses of appropriate DNA markers.

KEY WORDS: morphology, seed, phenotypic traits, provenance differentiation, ecocline. 